\title{
Comparative Study of Anthropometric Measurement and Body Composition Between Elite Handball and Volleyball Players from the Serbian National League
}

\author{
Estudio Comparativo de Medición Antropométrica y Composición Corporal entre \\ Jugadores de Balonmano y Voleibol de Élite de la Liga Nacional Serbia
}

Bojan Masanovic $^{1}$; Jovan Gardasevic ${ }^{1}$ \& Dusko Bjelica ${ }^{1}$

MASANOVIC, B.; GARDASEVIC, J. \& BJELICA, D. Comparative study of anthropometric measurement and body composition between elite handball and volleyball players from the serbian national league. Int. J. Morphol., 39(1):287-293, 2021.

SUMMARY: The purpose of this study was to describe the anthropometric characteristics and body composition of elite handball and volleyball players from the Serbian national league as well as to make comparisons between them. Sixty males were enrolled, divided into three groups: 15 handball players, 14 volleyball players, and 31 healthy sedentary subjects. All subjects were assessed for the anthropometric measures required for the calculation of body composition variables, using the standardized procedures recommended by established literature. Data were analysed using SPSS, and the descriptive statistics were expressed as a mean (SD) for each variable, while the ANOVA and LSD Post Hoc tests were carried out to detect the effects of each type of sport. The results showed there was no significant difference for body weight and body mass index, nor were there any differences for the bone contents of bodies among the groups, while significant differences were found for body height, as well as for muscle and fat content of body among the groups. These findings may give coaches from the region better working knowledge and enable them to follow recent selection process methods and to be more careful during talent identification.

KEY WORDS: Sport; Top athletes; Talent identification; Handball; Volleyball; Male.

\section{INTRODUCCIÓN}

The main task of modern athletic science is to improve the performance of athletes, identifying talents, strengths, and weaknesses as precisely as possible when assigning players positions and designing optimal training programmes (Popovic et al., 2013). Logically, an elite athlete that is competing in the strongest league is expected to have the optimal strength and endurance for the functional requirements of the sport in question (Bjelica et al., 2020). However, this does not mean that all attention should be directed to increasing the physical fitness of athletes without taking into account the assessment of their body composition and their nutritional status (Triki et al., 2012). Many studies have shown that specific anthropometric characteristics are significantly associated with success in sports (Lungile et al., 2017; Stephens \& Fourie, 2017), and various athletic events require appropriate body composition and body mass figures to achieve maximum performance (Krisepi et al., 2019). Therefore, understanding the body composition of athletes, and subsequently assigning appropriate competitive weight to them, is considered a crucial part of the overall management process (Gardasevic et al., 2020).

Body composition can affect strength and agility, whereas body mass can influence an athlete's speed, endurance, and power (Ramos-Campo et al., 2014). It is well known that excess fat mass compromises physical performance, acting as a dead mass in activities in which the body must be repeatedly lifted during locomotion and jumping, thus decreasing performance and increasing energy demands (Nikolaidis \& Karydis, 2011). For most sports, it is remedial ballast, but in some, it is necessary (Masanovic, 2019). In contrast, muscle-skeletal mass is an indicator of sports performance, because it contributes to energy production during high-intensity activities and provides absolute strength to athletes (Chulvi-Medrano et al., 2019). From this, it follows that modern athletes should be fast, capable of explosive movement, and powerful, and should have more muscle mass and less fat tissue. However, each sport has its specific 
requirements, and each athlete should have specific anthropometric characteristics and body composition figures for his sports discipline (Sitko et al., 2019). Therefore, the correct assessment of body composition in sports is essential, since errors may lead to mistakes in training prescription and diet design, and thus affect the athletic performance (Rodríguez-Rodríguez et al., 2019). Some sports, such as wrestling, boxing, and judo, require much more specific investigation into this topic, because of weight limits as well as favouring the selection of athletes with a limited vertical skeletal development (Popovic et al., 2013). As another example, the sport of arm-wrestling requires the selection of athletes with longer forearm bones (Akpinar et al., 2013). The need to investigate the anthropometrical characteristics and body composition numbers of handball and volleyball players is equally important, as adequate body composition and body mass figures, among other factors, contribute to optimal exercise routines and performance (Masanovic et al., 2018a).

In the literature, team handball is defined as an intermittent, high-intensity sport with high demands of physical capacity (Goristiaga et al., 2009). Hermassi et al . (2011) emphasize that handball is a strenuous contact sport that emphasizes running, jumping, sprinting, throwing, hitting, blocking, pushing, blocking, turning, changing speeds and grabbing opponents during games. From the literature point of view, pronounced body height, muscular strength and power, technical and tactical skills are the factors that give a clear advantage in high-level competitions (Marques et al., 2009). In contrast, in volleyball, movement patterns significantly differ from handball, as the dominance over the net is the most decisive factor for victory (Loureiro et al., 2017; Peña et al., 2018). Volleyball as a sport is characterized by short and frequent explosive activities, such as jumping, diving, and ball play (Sheppard et al., 2012). The game has many horizontal approaches, and durable jumping ability and a powerful reflection are also vital. Regarding anthropometric profiles, great body height, lean body and low fat percentage seem to be good advantages of high-level volleyball players (Sheppard et al.).

Most of the data on the characteristics of handball and volleyball players come from Western Europe, while far less come from Eastern Europe and the Western Balkan region. For this reason, it is necessary to check whether data collected on the anthropometric characteristics and body composition of Western Balkan athletes support previous studies that have evaluated the ideal anthropometric profiles of successful handball players and volleyball players (Gualdi-Russo \& Zaccagni, 2001; Srhoj et al., 2002; Chaouachi et al., 2009; Lidor \& Ziv, 2010). Therefore, the purpose of this study was to describe the anthropometric characteristics and body composition profiles of elite handball and volleyball players from the Serbian national league and to detect possible differences in relation to competition level.

\section{MATERIAL AND METHOD}

In the study, 60 males were enrolled. They were divided into three groups: 15 handball players $(23.13 \pm 2.20$ yrs.) from the handball premier league in Serbia, 14 volleyball players $(20.21 \pm 2.52$ yrs.) from the volleyball premier league in Serbia and 31 healthy sedentary subjects from the same country ( $24.94 \pm 3.10 \mathrm{yrs}$.). The measurements were carried out in the winter preparation period.

All subjects gave their written consent, and the local ethics committee approved the protocol of the study. All subjects were assessed for the 20 anthropometric measures required for the calculation of body composition variables, using the standardized procedure recommended by the International Biological Program (IBP) (Marfell-Jones et al., 2006). Height and weight were measured in the laboratory with the subject dressed in underwear. Height was measured to the nearest $0.1 \mathrm{~cm}$ using a fixed stadiometer, and weight was measured to the nearest $0.1 \mathrm{~kg}$ with a standard scale utilizing a portable balance. Skinfold thicknesses $(\mathrm{mm})$ were measured at six sites: triceps skinfold, forearm skinfold, thigh skinfold, calf skinfold, chest skinfold, and abdominal skinfold thickness (using a skinfold caliper). The circumferences $(\mathrm{cm})$ were measured at eight sites: minimum circumference of the upper arm, maximum circumference of the upper arm, minimum circumference of the forearm, maximum circumference of the forearm, minimum circumference of the upper leg, maximum circumference of the upper leg, minimum circumference of the lower leg, and maximum circumference of the lower leg (using an anthropometric tape). In the end, the following diameters were measured to the nearest $0.1 \mathrm{~cm}$ : elbow diameter, wrist diameter, knee diameter, ankle diameter (using a small siding caliper). To reduce measurement variation, the same investigator examined all the subjects.

Body mass index (BMI) was calculated as body mass in kilograms divided by height in meters squared $\left(\mathrm{kg} / \mathrm{m}^{2}\right)$ (Kovac et al., 2012). The values of bone, muscular, and fat contents of body composition were acquired by distributing all the measured variables in formulas by Mateigka (Matiegka, 1921).

The data obtained in the research were processed using the application statistics program SPSS 20.0 (Chicago, IL, USA), adjusted for use on personal computers. The 
descriptive statistics were expressed as a mean (SD) for each variable. Analysis of the variance (ANOVA) and the LSD Post Hoc test was carried out to detect the effects for each type of sport (handball or volleyball) on each variable: body height, body weight, body mass index (BMI), and muscle, bone and fat content of the body, as well as to control it with reference to the sedentary subjects. The significance was set at an alpha level of 0.05 .

\section{RESULTS}

The anthropometric characteristics of the subjects are shown in Table I. There were no significant differences for body weight and body mass index or for bone content of the
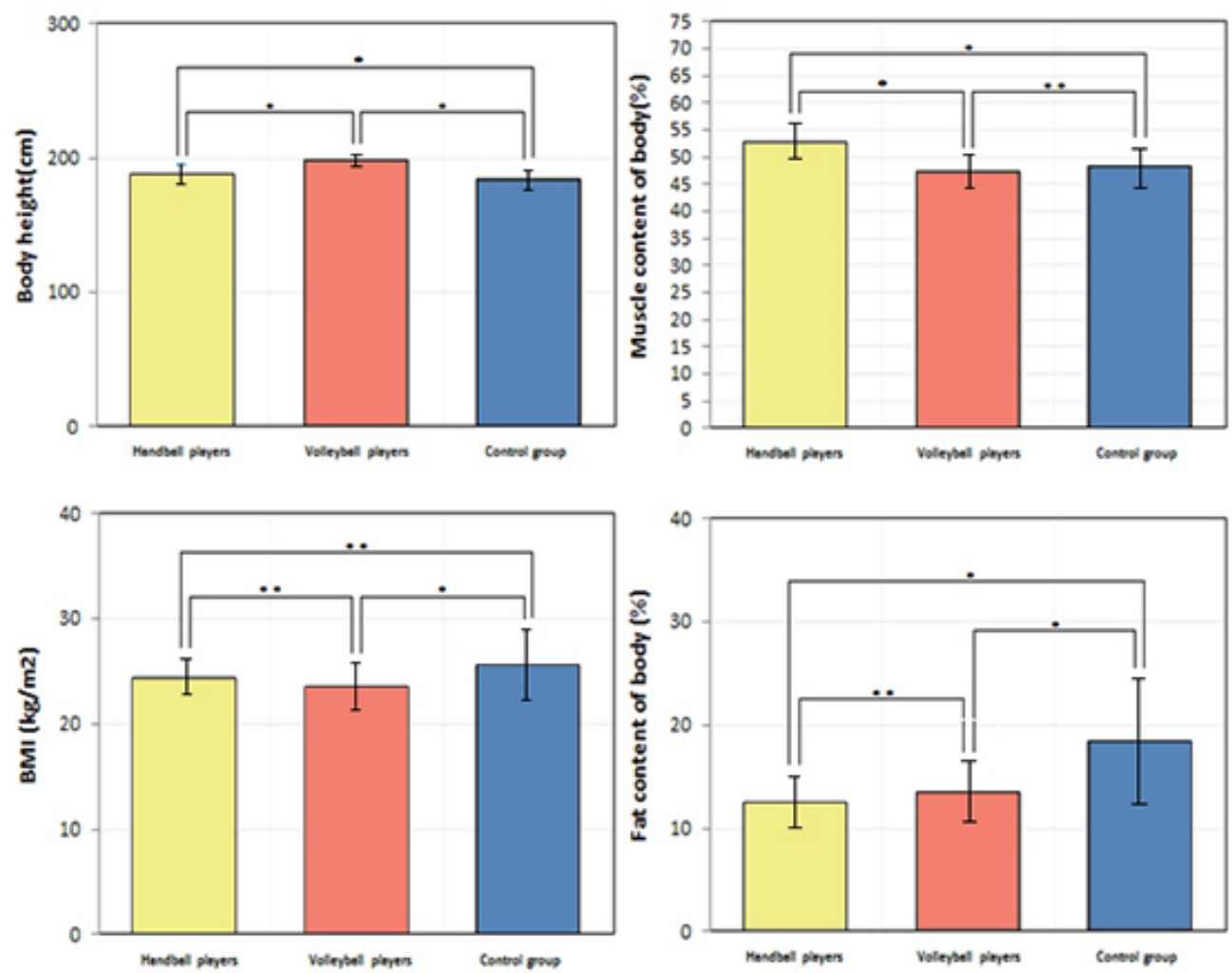

body among the groups, while a significant difference was found for body height $(\mathrm{F}=24.53)$, as well as for muscle (15.04) and fat content of body (10.96) among the groups.

The significant differences in anthropometric characteristics among particular sports are shown in Figure 1. The LSD Post Hoc test indicates that volleyball players were significantly taller than handball players and the subjects of the control group; also, a significant difference between the body height of handball players and the subjects of the control group was found. This test also indicates that subjects of the control group have significantly higher body mass index than handball and volleyball players, while no other differences were found in this parameter. The muscle content in the bodies of handball players is significantly higher than in volleyball players and the subjects of the control group, while no other differences in this content were found. The fat content in the bodies of handball and volleyball players is significantly lower than the percentage of fat content in the bodies of the control group, while no other differences were found for this factor associations between arms span measurements and stature among the above models is sketched as a scatter diagram (Fig. 1).

Fig. 1. LSD Post hoc test for the different parameters among the subject.

$* *=$ non-significant; $*$ = significant difference between the groups.

Table I. Anthropometric measurement and body composition among the subjects.

\begin{tabular}{lcccc}
\hline Variables & Handball $(\mathrm{N}=15)$ & Volleyball $(\mathrm{N}=14)$ & Control (N=31) & ANOVA \\
\cline { 2 - 4 } & \multicolumn{3}{c}{ Mean \pm Standard Deviation } \\
\hline Height $(\mathrm{cm})$ & $188.16 \pm 6.14$ & $198.53 \pm 3.89$ & $183.72 \pm 7.60$ & $0.000^{*}$ \\
Weight $(\mathrm{kg})$ & $86.63 \pm 7.49$ & $92.64 \pm 7.85$ & $86.50 \pm 14.70$ & $0.270^{\wedge}$ \\
BMI $(\mathrm{kg} / \mathrm{m} 2)$ & $24.47 \pm 1.71$ & $23.52 \pm 2.14$ & $25.61 \pm 3.49$ & $0.073^{\wedge}$ \\
Muscle content of body $(\%)$ & $52.85 \pm 3.26$ & $47.22 \pm 2.13$ & $48.32 \pm 3.27$ & $0.000^{*}$ \\
Bone content of body $(\%)$ & $15.29 \pm 1.14$ & $15.46 \pm 0.82$ & $14.78 \pm 1.78$ & $0.296^{\wedge}$ \\
Fat content of body $(\%)$ & $12.41 \pm 2.65$ & $13.57 \pm 2.52$ & $18.51 \pm 5.89$ & $0.000^{*}$ \\
\hline
\end{tabular}

$\mathrm{N}=$ number of subjects; ${ }^{\wedge}=$ non-significant; $*=$ significant difference between the groups. 


\section{DISCUSSION}

The results of this study support previous investigations indicating a significant difference regarding the body height among the handball and volleyball players from one side and the subjects from the control group that represents the general population on the other side (Popovic et al., 2014a; Masanovic et al., 2018b). Furthermore, a significant difference in body height is also observed between handball players and basketball players, which is also in line with the results of previous studies (Pena et al., 2018; Masanovic). The difference between athletes and healthy sedentary subjects confirms how the selection process is important for sport, while the observed differences between handball and volleyball players point to the different selection criteria that are associated with different types of play and different game rules between the handball and volleyball (Bayios et al., 2006; Masanovic).

The heights of handball players obtained in this study raise doubt that the selection process has been carried out correctly, especially because official statistical data indicated that handball players from Serbian national league are shorter than the most successful team of the IHF Men's Handball World Championship played in France 2017. For example, the average height teams that played semi-finals was 191.75 centimeters; the average height ideal team of the championship was 191.86; the average height of team vice-champion Norway was 193 centimeters; 7th-placed Hungary had an average of 195 centimeters; Kiril Lazarov $(197 \mathrm{~cm})$ from FYR Macedonia was the top goals scorer of championship its tall; Domagoj Duvnjak $(197 \mathrm{~cm})$ from Croatia was the best centre-back; France's captain Nikola Karabatic' was 196 centimeters tall. Also interesting is the fact that even teams from Africa, which are not among the best in the world, have a higher average height than the players from the Serbian national league. Also, 13th-placed Egypt had an average of 190 centimeters, and 19th-placed Tunisia had an average of 192 centimeters. Only the teams from Asia are comparably shorter than the majority of European Teams, 8th-placed Qatar had an average of 186 centimetres; 20th-placed Saudi Arabia had an average of 181 centimeters; 22nd-placed Japan had an average of 185 centimeters, and Serbian players are taller than them, but these are also teams that do not have good results. This fact provides one of the reasons that players from the Serbian handball team have not been on winning streaks in recent years. Therefore, this may give coaches from Serbia better knowledge of this particular group of athletes and suggest that they follow recent selection process methods. They should be more careful during the recruitment process as they have a very tall general population (Popovic et al., 2013; Grasgruber et al., 2019; Starc et al., 2019).
It is well known that a large proportion of very tall subjects seems to be characteristic of the people from this area, since $28 \%$ of people from the general population were measured as having 190 centimeters or more in body height (Pineau et al., 2005; Bjelica et al., 2012), which confirms the high score of the subjects from the control group (183.72 $\mathrm{cm})$.

In contrast, the average body heights of the volleyball teams who played the final CEV Men's Volleyball European Championship 2017 in Poland were next. The results in centimeters for each team: Russia 200.5, Germany 199.36, Belgium 198.64, Italy 197,43, Czech Republic 196.71. The average height of all participants in the championship was $197.58 \mathrm{~cm}$. This official statistical data proved that the players from the Serbian volleyball premier league are tall enough, and they do not lag behind the top players in Europe. Their body height allows handball and volleyball players to control actions in defense and attack more easily (Pena $e t$ al., 2018). Consequently, male professional handball and volleyball players, even the shortest players, are often above average in height compared to the general population (Popovic et al., 2014v). However, extra talented short players, especially those with a high vertical jump, shall also be selected and play a significant role (Masanovic).

Furthermore, no significant difference was found among the groups regarding body weight. Volleyball players were insignificantly heavier than handball players and the subjects of the control group, mostly because they are significantly taller than both groups. Handball players, as expected, have lower body weight than the most successful world players do. In contrast, the bodyweight of volleyball players obtained by this study corresponds to the weight of the most successful team from the IHF 2017 men's Handball World Championship played in France. For example, the average weight team of Russia, who won the championship, was 92.86 kilograms; 4th-ranked Belgium had an average of 92.43 kilograms.

The body mass index parameter, which is widely used in adult populations, is an internationally recognized definition of overweight and obesity; volleyball players are in the range of normal weight, according to the established literature, and have significantly lower scores than subjects from the control groups do. The body mass index of volleyball players obtained by this study also corresponds to the weights of the most successful team from the 2017 IHF Men's Handball World Championship played in France. For example, the average body mass index of all participants in the mentioned championship was 23.07. Conversely, the body mass index of handball players obtained in this study (24.47) is lower than the most successful world players, 
which proves the official statistical data according to which the average body mass index of the handball teams who played the finishing line in the 2017 IHF Men's Handball World Championship played in France were next: France 26.32, Slovenia 26.04, and Sweden 26.58.

Indeed, the authors found that the handball players had significantly higher muscle content than the subjects of the control group did. These results may also be explained by more demands to grow the muscle contents of the body in games that require intermittent activities when highintensity activities are followed by low-intensity movements (Buchheit et al., 2009), such as handball. It is known that this cannot have much effect on body height, because this is a highly genetically conditioned dimension. In contrast, the percentage of muscle can be changed significantly. Sometimes illegal substances are used for these purposes. Professional athletes mostly use anabolic-androgenic steroids to enhance performance (muscles grow, muscle strength and density increase; recovery is faster from workouts and muscle injury). The results of using these unauthorized pharmaceuticals are augmenting performance, but they bring consequences, including health risks. The volleyball players have the lowest muscle content among the group, but their muscle mass is corresponding to the values in the established literature (Jeukendrup \& Gleeson, 2009). The bone content of all groups is proportional to the longitudinal and transversal dimension of the skeleton and showed no significant differences among the groups.

Moreover, it was expected that the percentage of fat mass of the handball and volleyball players would be significantly lower than that of the control group. The low percentage of fat content in the body of Serbian handball and volleyball players showed that they have high physical performance, and these results could be explained by less physical activity in controls (Popovic et al., 2014a,b). Also, it is essential to remember that athletes in elite team sports, such as handball and volleyball, need a determined body fat percentage to perform adequately and achieve their full playing potential (Arifi et al., 2019). In contrast, people who have too little fat tissue are susceptible to certain risks. A large decline of fat levels can lead to complications and contraindications because adipose tissue is a complex, essential, and highly active metabolic and endocrine tissue that communicates with the central nervous system (Costa et al., 2011). In addition to energy storage, it also regulates energy metabolism via secreting adipokines (bioactive peptides) into circulation (Ozenoglu et al., 2008). Adipokines (leptin, adiponectin, and interleukin 6) play a role in a multitude of functions, in the regulation of energy consumption, in the proliferation of many normal and neoplastic tissues, in haematopoiesis and reproduction, and in the regulation of immune function
(Kershaw \& Flier, 2004). Also, they stimulate endothelial cell growth, accelerate wound healing, play an important role in bone development, have anti-diabetic, anti-inflammatory, and anti-atherogenic properties, help regulate responses to trauma, especially burns and other damaged tissues that lead to inflammation, and are is necessary for resistance against Streptococcus pneumoniae (Marginean et al., 2013). Inadequate adipose tissue weakens the body (Fischer, 2006). Through this interactive network, adipose tissue is integrally involved in coordinating a variety of biological processes (Fusaru et al., 2012). Thus, both excess and insufficient adipose tissues have harmful metabolic consequences and represent significant medical and socioeconomic burdens in the world today.

This study suggests that playing handball significantly increased the percentage of muscle content of the body, using the comparison of the control group, whose participants had a lower percentage of muscle content. This study also suggests that playing handball and volleyball significantly decreased the percentage of the fat content of the body, using the comparison of the control group, whose participants had a higher percentage of body fat. The part attributed to body height is the main factor in the selection process. Hence, an increased focus on these variables is essential. In contrast, the differences in body weight could be primarily caused by nutritional habits and the volume of physical activity. Finally, the bone content of the body is in accordance with body height and body weight.

Considering that the measurements were conducted in the middle of the season, this study is limited by the fact that changes in body composition and physical performance may occur from the start to the end of an athlete's training and competitive season. Kraemer et al. (2004) and Bjelica et al. (2020) reported that players who enter a season with a high catabolic metabolic status could experience reductions in performance during a competitive season accompanied by detrimental changes in body composition. Accordingly, further studies should be very careful in projecting timelines for measuring anthropometric characteristics and body composition, mostly because it has to be conducted either at the beginning or at the end of a season. It also has to be explicitly reported when the measurement was conducted.

The results of this research indicate the mistakes that are being made during the talent identification process by the coaches from Serbia. They also demonstrate the temporary distance from the top teams in the world as well as the ways the coaches should take in order to achieve globally excellent results. It is also worth mentioning that the players who want to have a successful performance at the top-quality competitions are required to possess those 
characteristics established by the standards for that sport; anthropometric measurement and body composition play a crucial role here. The new information that was generated in this study will aid in defining a more precise top handball player profile, which would be of value for the coaches' evaluation and which represents a considerable contribution of this research to the broader knowledge base.

AUTHOR CONTRIBUTIONS. Bojan Masanovic collected the data, wrote the manuscript, designed and led the study; Jovan Gardasevic performed statistical analyses and revised the manuscript; Dusko Bjelica overviewed previous studies and discussed the results, did the presentation of the results, discussed the results and revised the manuscript.

MASANOVIC, B.; GARDASEVIC, J. \& BJELICA, D. Estudio comparativo de medición antropométrica y composición corporal entre jugadores de balonmano y voleibol de élite de la liga nacional Serbia. Int. J. Morphol., 38(6):287-293, 2020.

RESUMEN: El objetivo de este estudio fue describir las características antropométricas y la composición corporal de los jugadores de balonmano y voleibol de élite de la liga nacional serbia, y realizar comparaciones entre ellos. Se evaluaron sesenta hombres divididos en tres grupos: 15 jugadores de balonmano, 14 jugadores de voleibol y 31 sujetos sedentarios sanos. Se evaluaron las medidas antropométricas de todos los sujetos requeridas para el cálculo de las variables de composición corporal, utilizando los procedimientos estandarizados recomendados por la literatura establecida. Los datos se analizaron mediante SPSS y las estadísticas descriptivas se expresaron como media (DE) para cada variable, mientras que se realizaron las pruebas ANOVA y LSD Post Hoc para determinar los efectos de cada tipo de deporte. Los resultados mostraron que no hubo diferencias significativas para el peso corporal y el índice de masa corporal, ni hubo diferencias para el contenido óseo de los cuerpos entre los grupos, mientras que se encontraron diferencias significativas de altura corporal, así como para el contenido de músculo y grasa corporal. Estos hallazgos pueden proveer un mejor conocimiento de trabajo a los entrenadores de la región y permitirles seguir los métodos recientes del proceso de selección y estar más atentos durante la identificación de talentos.

PALABRAS CLAVE: Deporte; Atletas Top; Identificación de talentos; Balonmano; Vóleibol; Masculino.

\section{REFERENCES}

Akpinar, S.; Zileli, R.; Senyüzlü, E. \& Tunca, S. Anthropological and perceptual predictors affecting the ranking in arm wrestling competition. Int. J. Morphol., 31(3):832-8, 2013.
Arifi, F.; Bjelica, D. \& Masanovic, B. Differences in anthropometric characteristics among junior soccer and handball players. Sport Mont, 17(1):45-9, 2019.

Bayios, I. A.; Bergeles, N. K.; Apostolidis, N. G.; Noutsos, K. S. \& Koskolo, M. D. Anthropometric, body composition and somatotype differences of Greek elite female basketball, volleyball and handball players. J. Sports Med. Phys. Fit., 46(2):271-80, 2006.

Bjelica, D.; Popovic, S.; Kezunovic M.; Petkovic J.; Jurak, G. \& Grasgruber, P. Body height and its estimation utilizing arm span measurements in Montenegrin adults. Anthropol. Noteb., 18(2):69-83, 2012.

Bjelica. D.; Masanovic, B. \& Krivokapic, D. A comparative study of anthropometric measurements and body composition between junior football and basketball players from the Serbian National League. Baltic J. Health Phys. Act., 12(1):11-19, 2020.

Buchheit, M.; Lepretre, P. M.; Behaegel, A. L.; Millet, G. P. \& Ahmaidi, S. Cardiorespiratory responses during running and sport-specific exercises in handball players. J. Sci. Med. Sport, 12(3):399-405, 2009.

Chaouachi, A.; Brughelli, M.; Levin, G.; Boudhina, N.; Cronin, J. \& Chamari, K. Anthropometric, physiological and performance characteristics of elite team-handball players. J. Sports Sci., 27(2):1517, 2009.

Chulvi-Medrano, I.; Picon-Martinez, M.; Garcia-Jaen, M.; Cortell-Tormo, J. M.; Alakhdar, Y. \& Laurentino, G. Neuromuscular adaptations after blood flow restriction training combined with nutritional supplementation: A preliminary study. Monten. J. Sports Sci. Med., 8(1):37-42, 2019.

Costa, S. S.; Blotta, R. M.; Meurer, L. \& Edelweis, M. I. A. Adipocyte morphometric evaluation and angiogenesis in the omentum transposed to the breast: a preliminary study. Clinics, 66(2):307-12, 2011.

Fischer, C. P. Interleukin-6 in acute exercise and training: What is the biological relevance? Exerc. Immunol. Rev., 12:6-33, 2006.

Fusaru, A. M.; Stanciulescu, C. E.; Surlin, V.; Taisescu, C.; Bold, A.; Pop, O. T.; Banita, I. M.; Craitoiu, S. \& Pisoschi, C. G. Role of innate immune receptors TLR 2 and TLR4 as mediators of the inflammatory reaction in human visceral adipose tissue. Rom. J. Morphol. Embryol., 53(3):693-701, 2012.

Gardasevic, J.; Bjelica, D.; Vasiljevic, I. \& Masanovic, B. Differences in body composition between young soccer players (U19) members of the best soccer clubs in Serbia, Bosnia and Herzegovina, and North Macedonia. Pedag. Phys. Cult. Sports, 24(4):175-180, 2020.

Grasgruber, P.; Prce, S.; Stracarova, N.; Hrazdíra, E.; Cacek, J.; Popovic, S.; Hrebíckova, S.; Potpara, P.; Davidovic, I. \& Kalina, T. The coast of giants: an anthropometric survey of high schoolers on the Adriatic coast of Croatia. PeerJ, 7:e6598, 2019.

Gualdi-Russo, E. \& Zaccagni, L. Somatotype, role and performance in elite volleyball players. J. Sports Med. Phys. Fit., 41(2):256-62, 2001.

Hermassi, S.; Chell, M. S.; Tabka, Z.; Shephard, R. J. \& Chamari, K. Effects of 8-week in-season upper and lower limb heavy resistance training on the peak power, throwing velocity, and sprint performance of elite handball players. J. Strength Cond. Res., 25(9):2424-33, 2011.

Jeukendrup, A. E. \& Gleeson, M. Sport Nutrition: An Introduction to Energy Production and Performance. Champaign, Human Kinetics, 2009.

Kershaw, E. E. \& Flier, J. S. Adipose tissue as an endocrine organ. $J$. Clin. Endocrinol. Metab., 89(6):2548-56, 2004.

Kovač, M.; Jurak, G. \& Leskosek, B. The prevalence of excess weight and obesity in Slovenian children and adolescents from 1991 to 2011. Anthropol. Noteb., 18(1):91-103, 2012.

Kraemer, W.; French, D.; Paxton, N.; Hakkinen, K.; Volek, J. S.; Sebastianelli, W. J.; Putukian, M.; Newton, R. U.; Rubin, M. R.; Gomez, A. L.; et al. Changes in exercise performance and hormonal concentrations over a Big Ten soccer season in starters and nonstarters. J. Strength Cond. Res., 18(1):121-8, 2004.

Lidor, R. \& Ziv, G. Physical characteristics and physiological attributes of adolescent volleyball players-a review. Pediatr. Exerc. Sci., 22(1):11434, 2010. 
Loureiro, M.; Hurst, M.; Valongo, B.; Nikolaidis, P.; Laporta, L. \& Afonso, $\mathrm{J}$. A comprehensive mapping of high-level men's volleyball gameplay through social network analysis: Analysing serve, side-out, side-out transition and transition. Monten. J. Sports Sci. Med., 6(2):35-41, 2017.

Lungile, B. M.; Sacha, J. W. \& Mogammad, S. T. Anthropometric and physical fitness characteristics of female basketball players in South Africa. S. Afr. J. Res. Sport Phys. Educ. Recreat., 39(3):93-103, 2017.

Marfell-Jones, M.; Olds, T.; Stew, A. D. \& Carter, J. E. L. International Standards for Anthropometric Assessment. Potchesfstroom, International Society for the Advancement of Kinanthropometry, 2006.

Marginean, C. O.; Man, L.; Pitea, A. M.; Man, A.; Marginean, C. \& Coto, O. S. The assessment between IL-6 and IL- 8 and anthropometric status in malnourished children. Rom. J. Morphol. Embryol., 54(4):935-8, 2013.

Marques, M. A. C.; Van Den Tillaar R.; Reis, V. M. \& González-Badillo, J. J. Physical fitness qualities of professional volleyball players: determination of positional differences. J. Strength Cond. Res., 23(4):1106-11, 2009.

Masanovic, B. comparative study of morphological characteristics and body composition between different team players from Serbian Junior National League: soccer, handball, basketball and volleyball. Int. J. Morphol., 37(2):612-9, 2019.

Masanovic, B.; Corluka, M. \& Milosevic, Z. Comparative Study of Anthropometric Measurement and Body Composition of Junior Soccer and Handball Players from the Serbian National League. Kinesiol. Slov., 24(3):37-46, 2018a.

Masanovic, B.; Milosevic, Z. \& Corluka, M. Comparative Study of Anthropometric Measurement and Body Composition between Junior Handball and Volleyball Players from Serbian National League. Int. J. Appl. Exerc. Physiol., 7(4):1-6, 2018b.

Matiegka J. The testing of physical efficiency. Am. J. Phys. Anthropol., 4:223-30, 1921.

Nikolaidis, P. T. \& Karydis, N. V. Physique and body composition in soccer players across adolescence. Asian J. Sports Med., 2(2):75-82, 2011.

Ozenoglu, A.; Balci, H.; Ugurlu, S.; Caglar, E.; Uzun, H.; Sarkis, C.; Gunay, C. \& Eker, E. The relationships of leptin, adiponectin levels and paraoxonase activity with metabolic and cardiovascular risk factors in females treated with psychiatric drugs. Clinics, 63(5):651-60, 2008.

Peña, J.; Moreno-Doutres, D.; Coma, J.; Cook, M. \& Buscà, B. Anthropometric and fitness profile of high-level basketball, handball and volleyball players. Rev. Andal. Med. Deporte, 11(1):30-5, 2018.

Pineau, J. C.; Delamarche P. \& Bozinovic, S. Average height of adolescents in the Dinaric Alps (in French). C. R. Biol., 328(9):841-6, 2005.

Popovic, S.; Akpinar, S.; Jaksic, D.; Matic, R. \& Bjelica, D. Comparative study of anthropometric measurement and body composition between elite soccer and basketball players. Int. J. Morphol., 31(2):461-7, 2013.

Popovic, S.; Bjelica, D.; Jaksic, D. \& Hadzic, R. Comparative study of anthropometric measurement and body composition between elite soccer and volleyball players. Int. J. Morphol., 32(1):267-74, 2014.

Popovic, S.; Bjelica, D.; Molnar, S.; Jaksic, D. \& Akpinar, S. Body Height and Its Estimation Utilizing Arm Span Measurements in Serbian Adults. Int. J. Morphol., 31(1):271-279, 2013.

Ramos-Campo, D. J.; Martínez-Sánchez, F.; Esteban-García, P.; RubioArias, J. A.; Bores, C. A.; Clemente-Suarez, V. J. \& Jiménez-Díaz, J. F. Body Composition Features in Different Playing Position of Professional Team Indoor Players: Basketball, Handball and Futsal. Int. J. Morphol., 32(4):1316-24, 2014.

Rodríguez-Rodríguez, F.; López-Fuenzalida, A.; Holway, F. \& Jorquera Aguilera, C. Diferencias antropométricas por posición de juego en futbolistas profesionales Chilenos. Nutr. Hosp., 36(4):846-53, 2019.

Sheppard, J. M.; Nolan E. \& Newton, R. U. Changes in strength and power qualities over two years in volleyball players transitioning from junior to senior national team. J. Strength Cond. Res., 26(1):152-7, 2012.

Sitko, S.; Cirer Sastre, R. \& López Laval, I. Effects of a low-carbohydrate diet on performance and body composition in trained cyclists. Nutr. Hosp., 36(6):1384-8, 2019.
Srhoj, V.; Marinovic, M. \& Rogulj, N. Position specific morphological characteristics of top-level male handball players. Coll. Antropol., 26(1):219-27, 2002

Starc, G.; Popovic, S.; Ordic, V.; Ostojic, S.; Music Milanovic, S.; Kujundzic, E.; Spiroski, I.; Uric, S.; Masanovic, B.; Sember, V.; et al. Differences in body height between the contemporary Western Balkan children and the WHO growth references core sample. Anthropol. Noteb., 25(3):55-67, 2019.

Stephens, D. \& Fourie, J. Morphological evolution of Springbok rugby players: Implications for racial transformation in South African rugby. S. Afr. J. Res. Sport Phys. Educ. Recreat., 39(3):145-61, 2017.

Triki, M.; Rebai, H.; Abroug, T.; Masmoudi, K.; Fellmann, N.; Zouari, M. \& Tabka, Z. Comparative study of body composition and anaerobic performance between football and judo groups. Sci. Sports, 27(5):2939, 2012

\section{Corresponding author: \\ Bojan Masanovic, PhD \\ University of Montenegro \\ Faculty for Sport and Physical Education \\ Narodne omladine bb \\ 81400 Niksic \\ MONTENEGRO}

\section{E-mail: bojanma@ucg.ac.me}

Received: 30-06-2020

Accepted: 07-09-2020 